\title{
Characterization of Inhalable Ground-Level Ambient Particulate Matter in Dhaka City, Bangladesh
}

\author{
A. A. Nayeem*, M. S. Hossain, A. K. Majumder \\ Center for Atmospheric Pollution Studies (CAPS), Department of Environmental Science, Stamford \\ University Bangladesh, Dhaka-1209, Bangladesh
}

Received 7 March 2020, accepted in final revised form 24 May 2020

\begin{abstract}
The capital Dhaka of Bangladesh is one of the most densely populated and air polluted cities in the world. This study is aimed to assess the trend of Particulate Matter $\left(\mathrm{PM}_{2.5}\right.$ and $\left.\mathrm{PM}_{10}\right)$ from 2013 to 2018 in relation to meteorological parameters. PM data were collected from the Continuous Air Monitoring Station (CAMS) at Darus Salam point in Dhaka city. CAMS gather air samples through beta gauge instrument which measures the volume of gas extracted through the stack/duct and calculates mass concentration. In the present study, $\mathrm{PM}_{2.5}$ was $54 \%$ of that of $\mathrm{PM}_{10}$ which is fine particulate matter. $\mathrm{PM}_{2.5}$ and $\mathrm{PM}_{10}$ had the lowest concentration in the month of July due to the highest rainfall rate whereas it was highest in the months of January and December. In addition, annual average concentration of $\mathrm{PM}_{2.5}$ and $\mathrm{PM}_{10}$ is observed to be 5-6 times higher than Bangladesh National Ambient Air Quality Standard (BNAAQS) while higher PM concentrations were observed in winter seasons. This study found significantly inverse association between ground-level PM and meteorological parameters in Dhaka city. Air pollution is deteriorating rapidly in Dhaka city and it is high time to implement the Clean Air Act urgently to reduce such destruction.
\end{abstract}

Keywords: Particulate Matter; Meteorology; Ratio; Trend; Variation.

(C) 2020 JSR Publications. ISSN: 2070-0237 (Print); 2070-0245 (Online). All rights reserved. doi: http://dx.doi.org/10.3329/jsr.v12i4.45802

J. Sci. Res. 12 (4), 701-712 (2020)

\section{Introduction}

Air pollution is a major threat to health of human being, whereas almost $91 \%$ of the world's population lives in most air polluted places in the world [1]. Particulate Matter (PM) especially fine particles $(\leq 2.5 \mu \mathrm{m})$ which do not settle down and have the capability to remain suspended in air are eventually recognized as one of the major elements of air pollution [2-4]. Ambient $\mathrm{PM}_{10}$ denotes the particleswith an aerodynamic diameter of $\leq 10$ $\mu \mathrm{m}$ and $\mathrm{PM}_{2.5}$ denotes $\leq 2.5 \mu \mathrm{m}$. These fine and coarse particles originate from biomass and fossil fuel burning, brick kilns, motorized vehicles, soil dust, pollen, sea spray etc. [5]. These particles are inhaled by living being and suffered from acute and chronic diseases

"Corresponding author: nayeem@stamforduniversity.edu.bd 
[6]. It has been determined that worldwide more than two million deaths each year occurreddue to lung and respiratory impairment because of fine particulate matter [7].

Dhaka is an overcrowded city, experiencing tremendous environmental problems in which air pollution is foremost [8]. It is among the 20 mega cities with around 20 million inhabitants (UN HABITAT) is suffering from severe air pollution problems [9]. According to IQAir report in 2019, Bangladesh has reached out top air polluted country in the world [10]. Apart from, air pollution poses Dhaka to become $2^{\text {nd }}$ least livable cities in the world [11]. PM along with other air pollutants is reported as the serious public health issue during the last three decades [12]. Fine particles $\left(\mathrm{PM}_{2.5}\right)$ are mainly generated from biomass and fossil fuel burning and gas to particle conversions through chemical processes in the atmosphere while coarse particles $\left(\mathrm{PM}_{10}\right)$ are produced from mechanical activities such as wind-blown dust, grindings, suspended road dust etc. [13]. The mass concentration as well as size distribution is the major characters of PM [14] which could reflect the lifetime physical and chemical properties of PM [15]. Receptor modeling studies found $50 \%$ of fine particles i.e., $\mathrm{PM}_{2.2}$ are originated from vehicles, $\mathrm{PM}_{2.2}-\mathrm{PM}_{10}$ from mechanical processes [16] whereas $35 \%$ of ambient $\mathrm{PM}_{10}$ and $15 \%$ of $\mathrm{PM}_{2.5}$ were found to be originated from brick kilns emissions $[1,9,16]$.

Characterization, source identification, estimation are important to regulate the pollutant sources, strategy development as well as to reduce the adverse impacts of air pollution related health effects $[17,18]$. A number of studies showed that, the ratio of fine particulate matter is high in Dhaka city particularly in winter season which mainly comes from burning process and vehicle activities [19-21]. Brick kilns are operated in dry season (November to May) where the PM concentrations were found to be high in comparison to any other seasons of the year [9]. A study done by Nayeem et al. found that strong and positive correlation between $\mathrm{PM}_{2.5}$ and number of brick kilns in Dhaka city and its vicinity [4]. Besides, the fine particles were high in predominantly motorized areas compared to vehicle free and non-motorized areas in Dhaka city [8]. Salam et al. found the total average concentrations of suspended particulate matter (SPM), $\mathrm{PM}_{10}$ and $\mathrm{PM}_{2.5}$ were 263, 75.5 and $66.2 \mu \mathrm{g} / \mathrm{m}^{3}$, respectively and the average $\mathrm{PM}_{2.5}$ mass was $88 \%$ of that of $\mathrm{PM}_{10}$ in Dhaka city [20]. Study indicates higher concentration of fine particle during winter seasons (2012-2015) in Dhaka, Gazipur, and Narayanganj while most of the time this pollution was related with the north-westerly wind [13].

The previous studies focused on characterization of average annual atmospheric pollutants for different locations whereas some were conducted during the dry season or only one season and specific source oriented (e.g., baby taxy ban, condensed natural gas introduction) spatiotemporal and diurnal variations with different time in Dhaka city [5,20-23]. This study has analyzed the updated data of both $\mathrm{PM}_{2.5}$ and $\mathrm{PM}_{10}$ concentration in Dhaka city from 2013-2018 in relation to meteorological parameters. The monthly and annual average ratio of PM has also been described which will illustrate the relationship between meteorology and PM characteristics to the policy making aspects. 


\section{Materials and Methods}

\subsection{Site description}

The climate of Bangladesh is comprised of high temperatures, excessive humidity, and distinctly marked seasonal variations in precipitation. Bangladesh can be divided into four seasons: pre-monsoon (March-May), monsoon (June-September), post-monsoon (October-November), and winter (December-February) [20]. Darus Salam CAMS (Fig. 1) is located at the Mass Communication Institute at Darus Salam area in Dhaka city. The roof height is about $7 \mathrm{~m}$ above the ground and the intake nozzle of the sampler is located $1.8 \mathrm{~m}$ above the roof. This place is also characterized by heavy traffic. Enormous vehicles from the northern part of the country come into this city through this way. A major portion of brick kiln clusters are also close to this station. This CAMSis situated about 100 meters away from the main road.

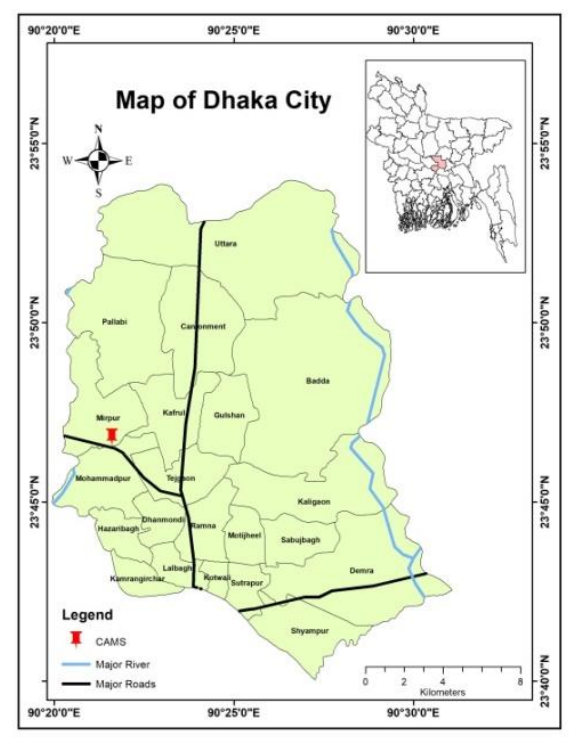

Fig. 1. Map of Dhaka city indicates the CAMS location.

\subsection{Data collection}

Monthly PM data has been collected from Darus Salam CAMS which is operated by the Department of Environment (DoE) under the project of Clean Air and Sustainable Environment (CASE). The air samples are collected through beta gauge instrument which measures the volume of gas extracted through the stack/duct and calculates mass concentration. The principle of beta attenuation particulate sampling instruments (beta gauge) is that energy is absorbed from beta particles as they pass through PM collected on a filter media [24]. The monthly rainfall data from 2013-2018 collected from the 
Bangladesh Meteorological Department (BMD) and monthly temperature and humidity data were collected from Darus Salam CAMS Station. All collected data were analyzed and visualized via the Statistical Package for Social Science (SPSS v.20) and MS Excel software.

\section{Results and Discussion}

\subsection{Monthly concentration of PM}

Average maximum $\mathrm{PM}_{2.5}$ concentration was $117 \mu \mathrm{g} / \mathrm{m}^{3}$ in 2013 while the minimum was $79 \mu \mathrm{g} / \mathrm{m}^{3}$ in 2016. The average maximum and minimum $\mathrm{PM}_{10}$ were found to be 182 and $145 \mu \mathrm{g} / \mathrm{m}^{3}$ in 2015 and 2017 respectively (Table 1). Over these years, both concentrations were found as the highest in January and December while the lowest was in July (Figs. 2 and 3). Aside of, PM concentration was minimum from April-August and gradually the trend increased from September. Similar result was also found by Rouf et al. for 20022005 in Dhaka city which showed PM concentration was less than BNAAQS for $24 \mathrm{~h}$ in raining months where daily variation was also higher in the winter than in the rainy season [2]. There is another study on Chattogram city and PM concentration was within standard level during April-October, but increased about three times higher than BNAAQS during the dry period [25]. There was also a similarity in relationship between PM concentration and seasonal characteristics in India, the average daily concentrations of $\mathrm{PM}_{2.5}$ and $\mathrm{PM}_{10}$ were $15.16-536.5 \mu \mathrm{g} / \mathrm{m}^{3}$ and $44.66-646.3 \mu \mathrm{g} / \mathrm{m}^{3}$, in India while in China were $6.03-126.03$ $\mu \mathrm{g} / \mathrm{m}^{3}$ and $15.58-217.04 \mu \mathrm{g} / \mathrm{m}^{3}$, during 2014-2017 respectively [26]. Eventually, it reveals the trend of $\mathrm{PM}_{2.5}$ is increased over the years though it decreased in 2016 but again amplified from 2017 (Fig. 4). The present study shows that $\mathrm{PM}_{2.5}$ concentration is almost five to six times higher than both BNAAQS $\left(15 \mu \mathrm{g} / \mathrm{m}^{3}\right)$ and WHO standard $\left(10 \mu \mathrm{g} / \mathrm{m}^{3}\right)$. The maximum $\mathrm{PM}_{10}$ concentration was $183 \mu \mathrm{g} / \mathrm{m}^{3}$ in 2015 and the minimum was 145 $\mu \mathrm{g} / \mathrm{m}^{3}$ in 2017 . $\mathrm{PM}_{10}$ concentration is also three times higher than BNAAQS $\left(50 \mu \mathrm{g} / \mathrm{m}^{3}\right)$ and almost six times higher than WHO standard $\left(25 \mu \mathrm{g} / \mathrm{m}^{3}\right)$.

Table 1. The monthly average values of $\mathrm{PM}_{2.5}$ and $\mathrm{PM}_{10}$ in Dhaka city during 2013-2018.

\begin{tabular}{lllllllllllllll}
\hline Year & $\begin{array}{l}\text { PM } \\
\left(\mu \mathrm{g} / \mathrm{m}^{3}\right)\end{array}$ & Jan & Feb & Mar & Apr & May & Jun & Jul & Aug & Sep & Oct & Nov & Dec & Avg. \\
\hline 2013 & $\mathrm{PM}_{2.5}$ & 227 & 150 & 130 & 66 & 367 & 34 & 22 & 25 & 44 & 50 & 107 & 181 & 117 \\
& $\mathrm{PM}_{10}$ & 301 & 248 & 248 & 136 & 73 & 73 & 53 & 52 & 93 & 89 & 191 & 277 & 153 \\
\hline \multirow{2}{2}{2014} & $\mathrm{PM}_{2.5}$ & 182 & 154 & 91 & 89 & 46 & 38 & 24 & 30 & 39 & 67 & 171 & 185 & 93 \\
& $\mathrm{PM}_{10}$ & 264 & 244 & 241 & 176 & 92 & 72 & 47 & 48 & 74 & 99 & 286 & 270 & 159 \\
\hline 2015 & $\mathrm{PM}_{2.5}$ & 178 & 142 & 123 & $\mathrm{NC}$ & $\mathrm{NC}$ & 44 & 26 & 32 & 52 & 63 & 121 & 190 & 97 \\
& $\mathrm{PM}_{10}$ & 247 & 241 & 235 & $\mathrm{NC}$ & 91 & $\mathrm{NC}$ & $\mathrm{NC}$ & 50 & 113 & 131 & 243 & 291 & 182 \\
\hline 2016 & $\mathrm{PM}_{2.5}$ & 212 & $\mathrm{NC}$ & 123 & 45 & 51 & 32 & 19 & 32 & 33 & 44 & 105 & 169 & 79 \\
& $\mathrm{PM}_{10}$ & 353 & 285 & 235 & $\mathrm{NC}$ & 100 & 72 & 44 & 70 & 63 & 92 & 188 & 272 & 161 \\
\hline 2017 & $\mathrm{PM}_{2.5}$ & 184 & 160 & 93 & 56 & 48 & 30 & 30 & 33 & 41 & 53 & 107 & 147 & 82 \\
& $\mathrm{PM}_{10}$ & 300 & 303 & 167 & 105 & 27 & 57 & 61 & 73 & 77 & 111 & 197 & 257 & 145 \\
\hline 2018 & $\mathrm{PM}_{2.5}$ & 209 & 167 & 119 & 75 & 53 & 38 & 33 & 26 & 46 & 134 & 134 & 170 & 100 \\
& $\mathrm{PM}_{10}$ & 327 & 321 & 247 & 140 & 89 & 78 & 71 & 62 & 103 & 248 & 248 & 236 & 181 \\
\hline * NC & $\mathrm{Not}_{2}$ Counted & & & & & & & & & & & &
\end{tabular}

$* \mathrm{NC}=$ Not Counted 


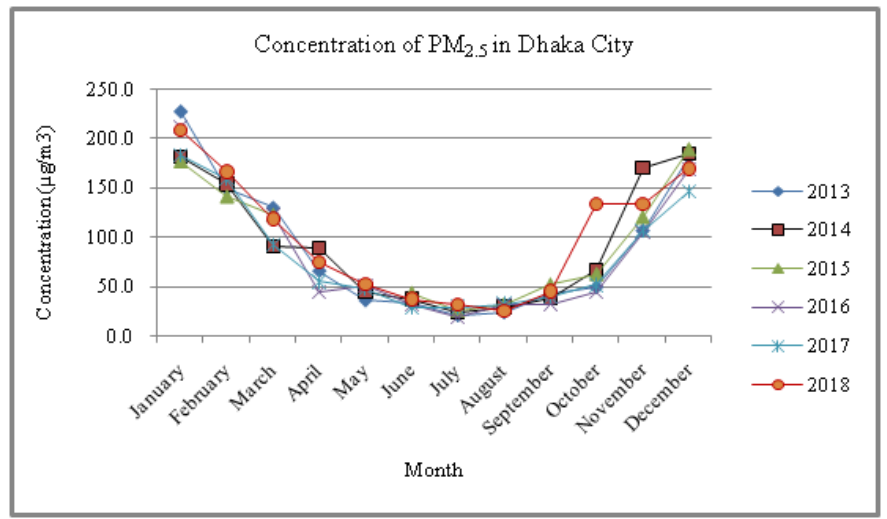

Fig. 2. Monthly average concentration of $\mathrm{PM}_{2.5}$ in Dhaka city from 2013-2018.

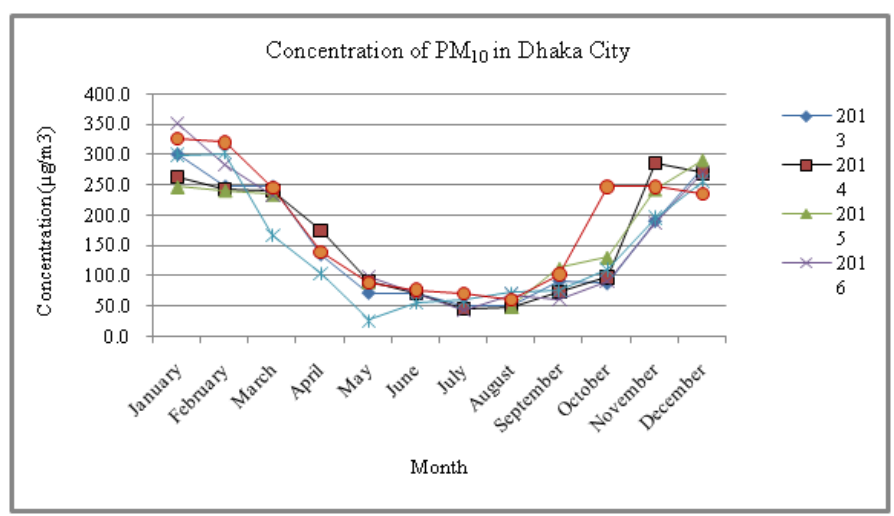

Fig. 3. Monthly average concentration of $\mathrm{PM}_{10}$ in Dhaka city from 2013-2018.
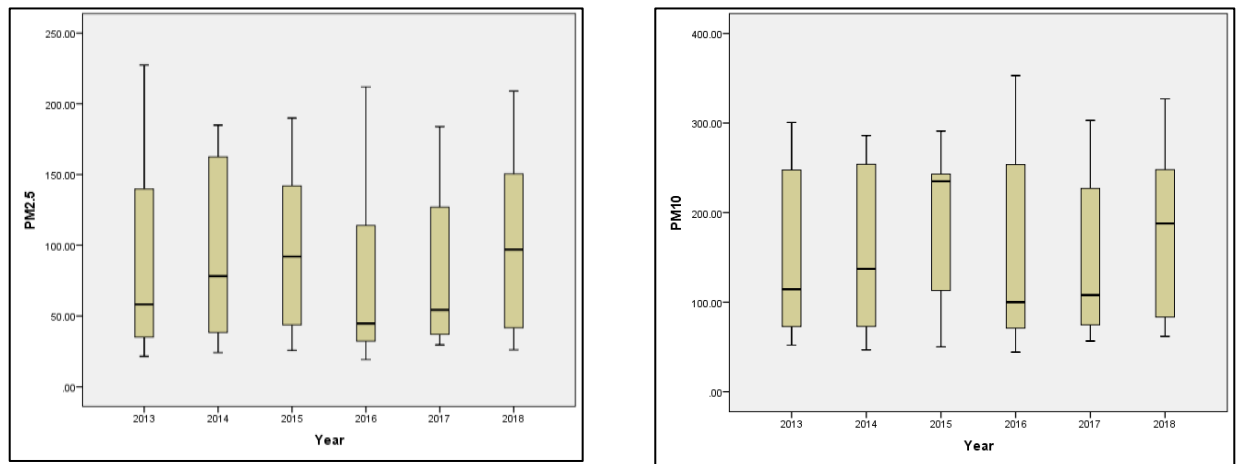

Fig. 4. Box and Whisker plot representing the annual concentration of PM in Dhaka city from 20132018. Horizontal black line within the box marks the median; the lower boundary of the box indicates the 25th percentile and the upper boundary of the box indicates the 75th percentile. The upper whisker represents the maximum and lower whisker represents the minimum value 


\subsection{Seasonal variation of particulate matter}

$\mathrm{PM}_{2.5}$ and $\mathrm{PM}_{10}$ had the lowest concentration in the month of July due to the highest rainfall rate whereas it was the highest in the months of January and December (Figs. 5 and 6). The maximum concentration of $\mathrm{PM}_{2.5}$ and $\mathrm{PM}_{10}$ were $186 \mu \mathrm{g} / \mathrm{m}^{3}$ in 2013 and 303 $\mu \mathrm{g} / \mathrm{m}^{3}$ in 2016 respectively during the winter season. The high emissions from brick kiln industries around Dhaka city are thought to contribute to the increased PM concentrations [27]. In addition, the suspended road dust, and soil dust also amplified the PM concentration during winter. The high and low-level concentration of $\mathrm{PM}_{2.5}$ and $\mathrm{PM}_{10}$ during winter and the monsoon season indicate a strong seasonal influence on air pollutionin Dhaka city [28]. During the winter season brick kilns start their production which contributes to total air pollution with the other sources in Dhaka city [29]. The evidence also showed that high concentration of PM during the winter season is caused by the seasonal fluctuations and transportation of the pollutants from the north and northwesterly directions of air [30,31] that also indicates the PM concentration is influenced by transboundary emission, especially in winter season [30].

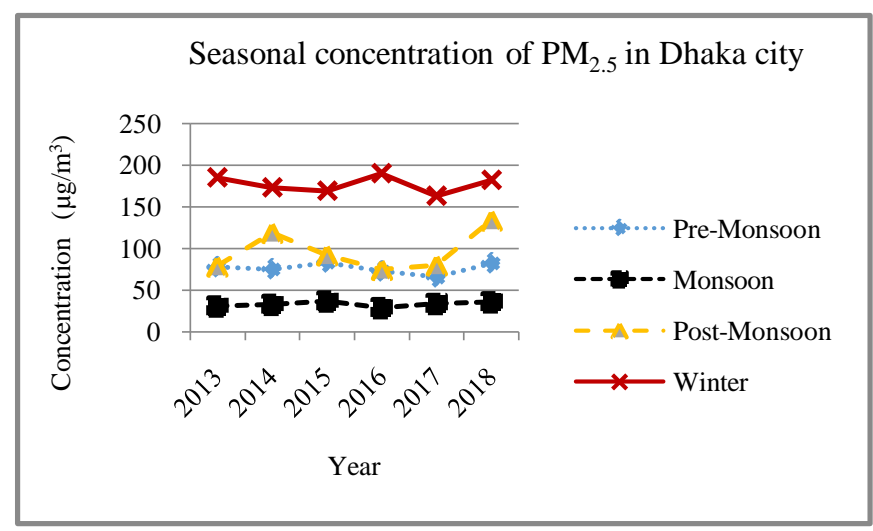

Fig. 5. Seasonal average concentration of $\mathrm{PM}_{2.5}$ in Dhaka city from 2013-2018.

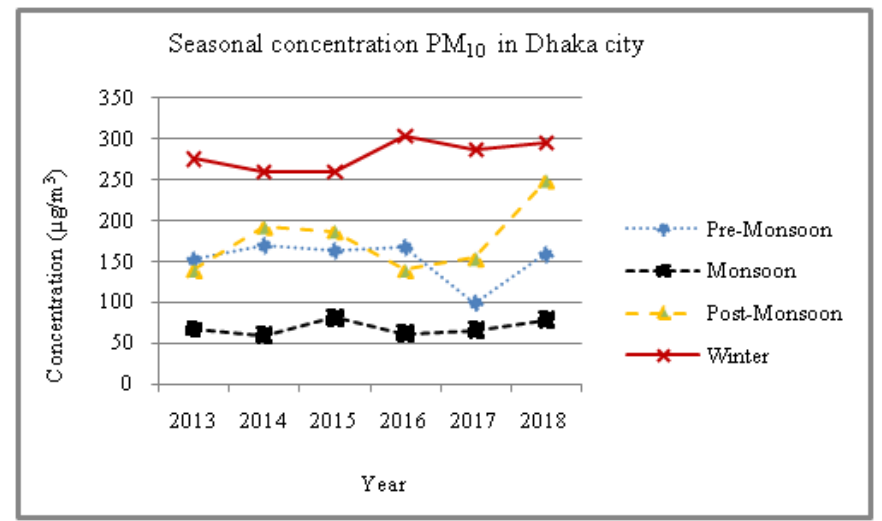

Fig. 6. Seasonal average concentration of $\mathrm{PM}_{10}$ in Dhaka city from 2013-2018. 


\subsection{Relationship and ratio between $P M_{2.5}$ and $P M_{10}$}

This study observed a strong correlation $\left(\mathrm{R}^{2}=0.97\right)$ between the monthly concentration of $\mathrm{PM}_{10}$ and $\mathrm{PM}_{2.5}$ from 2013-2018 that shows a parallel increasing trend of fine particles and coarse (Fig. 7). The ratio between average $\mathrm{PM}_{2.5}$ and $\mathrm{PM}_{10}$ concentration was found to be $0.54(54 \%)$. The highest ratio was observed in the winter season (0.65) followed by the pre-monsoon season (0.54) whereas the lowest ratio was 0.49 during the monsoon season which represented the significant influence of meteorological variables on PM ratio in Dhaka city (Table 2 ).

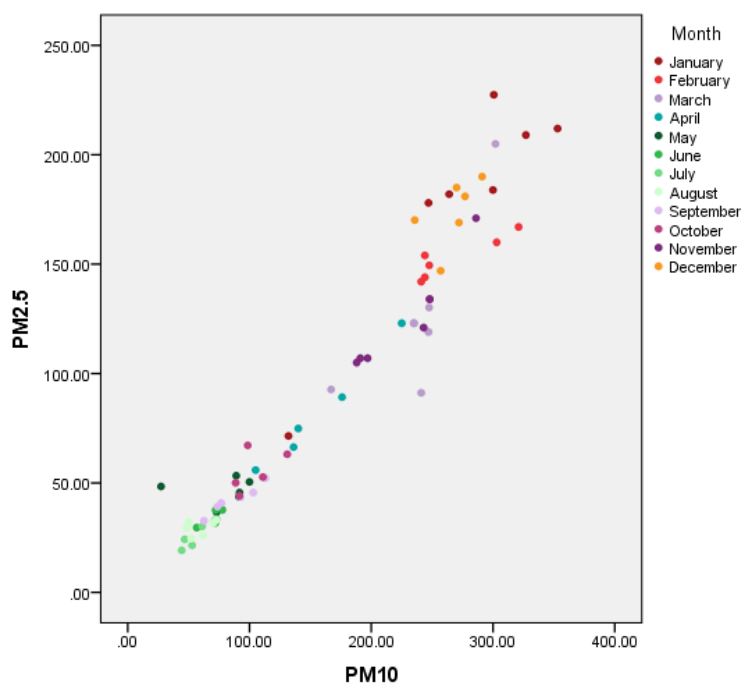

Fig. 7. Relationship between $\mathrm{PM}_{2.5}$ and $\mathrm{PM}_{10}$.

Table 2. Particulate Matter ratio in different seasons from 2013-2018 in Dhaka city.

\begin{tabular}{lll}
\hline Season & Mean & Std. Deviation \\
\hline Pre-Monsoon & 0.51 & 0.47 \\
Monsoon & 0.49 & 0.06 \\
Post-Monsoon & 0.54 & 0.06 \\
Winter & 0.65 & 0.07 \\
Whole Monitoring Period (2013-2018) & 0.54 & 0.08 \\
\hline
\end{tabular}

Fig. 8 represents that the $\mathrm{PM}_{2.5}$ fraction is less in rainy months particularly in June to July and higher in winter months (December-February). Several studies found the average ratio between 0.4-0.9 that may vary spatially and temporally [14,19,20,32]. In this study, $\mathrm{PM}_{2.5}$ ratio observed as $54 \%$ of $\mathrm{PM}_{10}$ which is mainly representing the sources of $\mathrm{PM}$ as fossil fuel [20]. Brick kilns and vehicles emission are the main sources of fine particles $\left(\mathrm{PM}_{2.5}\right)$ where coarse particles are assumed to be generated from mechanical processes [33]. The most considerable reasons for the higher ratio of $\mathrm{PM}_{2.5}$ in the winter season are 
portraying primary sources by anthropogenic activities and secondary particulate formation by the atmospheric chemical reactions such as $\mathrm{NO}_{3}{ }^{-}, \mathrm{SO}_{4}{ }^{2-}, \mathrm{NH}_{4}{ }^{+}$, and organics $[29,32,34]$.

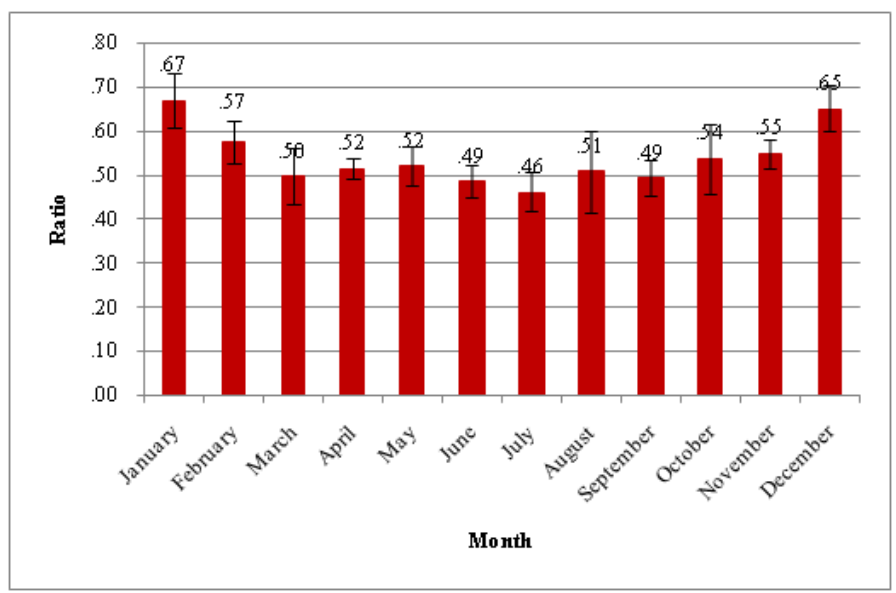

Fig. 8. Monthly average ratio of $\mathrm{PM}_{2.5} / \mathrm{PM}_{10}$ from 2013-2018.

\subsection{Relationship between particulate matter and meteorological parameters}

This study reveals a significantly negative association among PM and meteorological parameters (Table 3). Specifically, the concentration of fine particulate matter $\left(\mathrm{PM}_{2.5}\right)$ and coarse particulate matter $\left(\mathrm{PM}_{10}\right)$ resulted significantly inverse correlation with rainfall across the years. This study also observed the significantly strongly inverse relationship among $\mathrm{PM}_{2.5}$ and $\mathrm{PM}_{10}$ with temperature though the negative relationship with humidity was not consistently significant. Both $\mathrm{PM}_{2.5}$ and $\mathrm{PM}_{10}$ were moderately correlated with humidity in 2014 and 2015. Fig. 9 presents the seasonal relationship between PM and Meteorological parameters in Dhaka city. It indicates that, monsoon seasons had the highest rainfall rate which forced to drop the concentration of particles. Due to rainfall in monsoon season particulate matter may deposit in the ground though there is a chance to increase the PM concentration by drying up during the high summer temperature after rain [35]. Similar observations in Bangladesh were observed, the PM pollutants resulted negative correlationwith rainfall, atmospheric temperature during the study period [35]. Another study in Chattogram city shows the same trend of PM fluctuations with metrological variables from 2013-2018 [36]. Increasing rate of humidity and temperature especially in monsoon seasons forced to decrease the particles concentration significantly. Eventually, winter seasons had the highest PM concentration due to low temperature, humidity and rainfall rate. 
Table 3. Correlation between PM and metrological parameters in Dhaka city.

\begin{tabular}{|c|c|c|c|c|c|}
\hline Year & & & Rainfall & Humidity & Temperature \\
\hline \multirow{4}{*}{2013} & \multirow{2}{*}{$\mathrm{PM}_{2.5}$} & Pearson Correlation & $-.770^{* *}$ & $-.687^{* *}$ & $-.921^{* *}$ \\
\hline & & Sig. & .002 & .007 & .000 \\
\hline & \multirow{2}{*}{$\mathrm{PM}_{10}$} & Pearson Correlation & $-.824^{* *}$ & $-.797^{* *}$ & $-.848^{* *}$ \\
\hline & & Sig. & .000 & .001 & .000 \\
\hline \multirow{4}{*}{2014} & \multirow{2}{*}{$\mathrm{PM}_{2.5}$} & Pearson Correlation & $-.783^{* *}$ & -.179 & $-.834^{* *}$ \\
\hline & & Sig. & .001 & .289 & .001 \\
\hline & \multirow{2}{*}{$\mathrm{PM}_{10}$} & Pearson Correlation & $-.830^{* *}$ & -.438 & $-.792^{* *}$ \\
\hline & & Sig. & .000 & .077 & .003 \\
\hline \multirow{4}{*}{2015} & \multirow{2}{*}{$\mathrm{PM}_{2.5}$} & Pearson Correlation & $-.791^{* *}$ & $-.565^{*}$ & $-.934^{* *}$ \\
\hline & & Sig. & .003 & .045 & .000 \\
\hline & \multirow{2}{*}{$\mathrm{PM}_{10}$} & Pearson Correlation & $-.865^{* *}$ & $-.630^{*}$ & $-.840^{* *}$ \\
\hline & & Sig. & .001 & .034 & .002 \\
\hline \multirow{4}{*}{2016} & \multirow{2}{*}{$\mathrm{PM}_{2.5}$} & Pearson Correlation & $-.700^{* *}$ & $-.521^{*}$ & $-.959^{* *}$ \\
\hline & & Sig. & .008 & .050 & .000 \\
\hline & \multirow{2}{*}{$\mathrm{PM}_{10}$} & Pearson Correlation & $-.785^{* *}$ & $-.641^{*}$ & $-.922^{* *}$ \\
\hline & & Sig. & .002 & .017 & .000 \\
\hline \multirow{4}{*}{2017} & \multirow{2}{*}{$\mathrm{PM}_{2.5}$} & Pearson Correlation & $-.861^{* *}$ & $-.731^{* *}$ & $-.966^{* *}$ \\
\hline & & Sig. & .000 & .003 & .000 \\
\hline & \multirow{2}{*}{$\mathrm{PM}_{10}$} & Pearson Correlation & $-.798^{* *}$ & $-.709^{* *}$ & $-.955^{* *}$ \\
\hline & & Sig. & .001 & .005 & .000 \\
\hline \multirow{4}{*}{2018} & \multirow{2}{*}{$\mathrm{PM}_{2.5}$} & Pearson Correlation & $-.746^{* *}$ & $-.713^{* *}$ & $-.945^{* *}$ \\
\hline & & Sig. & .003 & .007 & .000 \\
\hline & \multirow{2}{*}{$\mathrm{PM}_{10}$} & Pearson Correlation & $-.788^{* *}$ & $-.814^{* *}$ & $-.841^{* *}$ \\
\hline & & Sig. & .001 & .001 & .000 \\
\hline
\end{tabular}

**Correlation is significant at the $\alpha=0.01$ level

*Correlation is significant at the $\alpha=0.05$ level
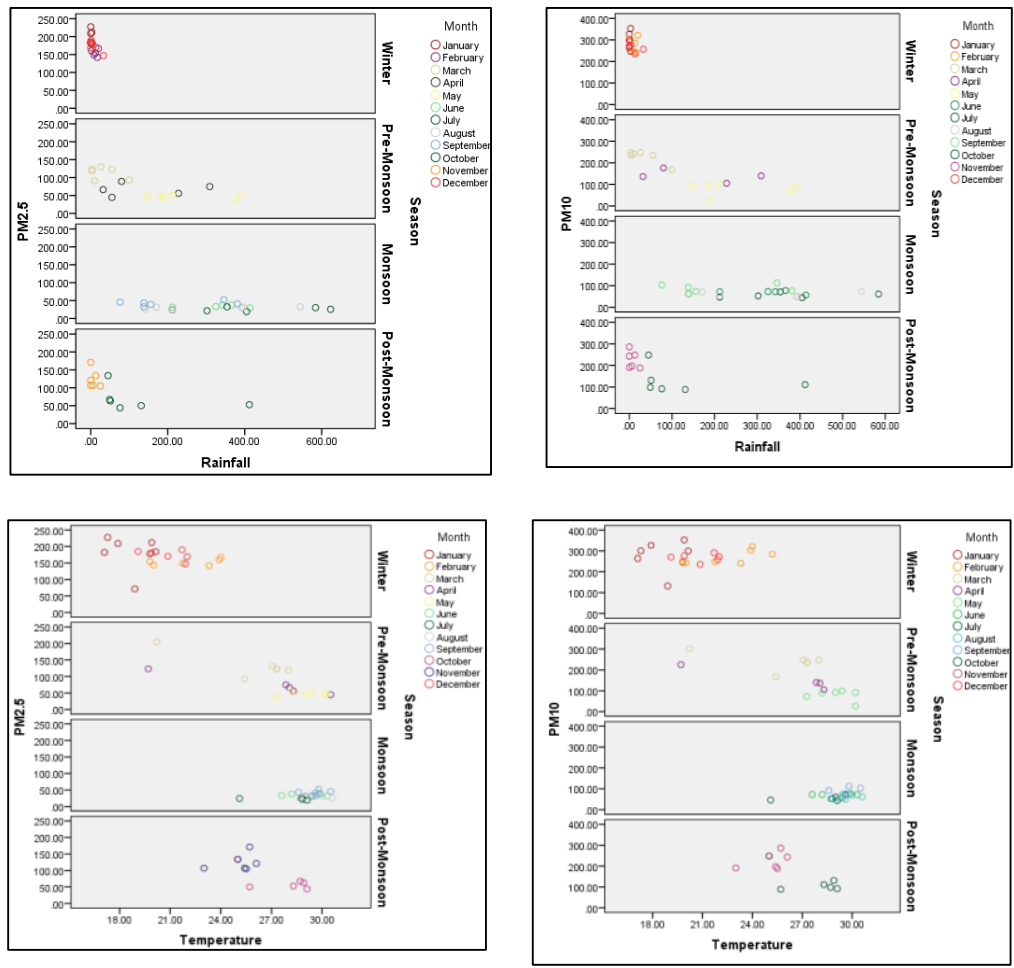

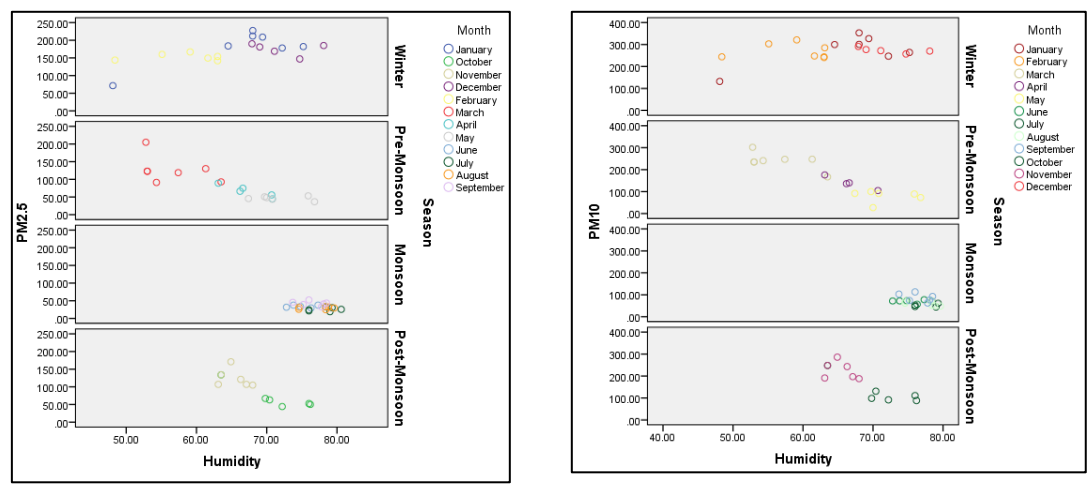

Fig. 9. Seasonal relation between PM and meteorological parameters.

\section{Conclusion}

This study scrutinized the characteristics of PM in relation to the meteorological phenomenon in Dhaka city over the years of 2013-2018. Higher $\mathrm{PM}_{2.5}$ and $\mathrm{PM}_{10}$ found in the winter season (Dec-Feb) while it is lower in the monsoon season (June-Sep). The $\mathrm{PM}_{2.5}$ and $\mathrm{PM}_{10}$ concentration are almost five-six and three-six folds higher than both BNAAQS (15 and $\left.50 \mu \mathrm{g} / \mathrm{m}^{3}\right)$ and WHO standard $\left(10\right.$ and $\left.25 \mu \mathrm{g} / \mathrm{m}^{3}\right)$ respectively. The Pearson correlation between $\mathrm{PM}_{2.5}$ and $\mathrm{PM}_{10}$ is also strongly positive $\left(\mathrm{R}^{2}=0.97\right)$. In this study, $\mathrm{PM}_{2.5}$ ratio detected $54 \%$ of that of $\mathrm{PM}_{10}$ and $\mathrm{PM}_{2.5}$ fractions are less in rainy months especially in June and July and higher in winter months (Dec to Feb). The higher ratio of $\mathrm{PM}_{2.5}$ during winter season denotes that, $\mathrm{PM}_{2.5}$ is generated from primary sources by anthropogenic activities and secondary particulate formation by chemical reaction. Apart from, this study also found significantly inverse association among meteorological parameters (rainfall, temperature and humidly) and particulate matters.

\section{Acknowledgment}

Particulate matter and meteorological data were provided by the Clean Air and Sustainable Development (CASE) project of Department of Environment, Ministry of Environment, Forest and Climate Change of the Government of Bangladesh and Bangladesh Meteorological Department (BMD) respectively. The authors are sincerely grateful to CASE and BMD for providing the data to accomplish this study.

\section{References}

1. WHO, Air Pollution (2020). http://www9.who.int/airpollution/en/

2. M. A. Rouf, M. Nasiruddin, A. M. S. Hossain, and M. S. Islam, Bang. J. Sci. Indust. Res. 46, 389 (2011). https://doi.org/10.3329/bjsir.v46i3.9049

3. M. M. Rana, M. H. Khan, M. A. K. Azad, S. Rahman, and S.A. Kabir, J. Sci. Res. 12, 15 (2020). https://doi.org/10.3329/jsr.v12i1.41501

4. A. A. Nayeem, M. S. Hossain, A. K. Majumder, and W. S. Carter, Int. J. Environ. Pollut. Environ. Model. 2, 277 (2019). https://ijepem.com/article/view/volume-2-issue-5-article-5 
5. B. A. Begum, M. Nasiruddin, S. Randal, B. Sivertsen, and P. K. Hopke, Brit. J. Appl. Sci. Technol. 4, 3930 (2014). https://doi.org/10.9734/BJAST/2014/11247

6. I. S. Abdul-Khalek, D. B. Kittelson, B. R. Graskow, Q. Wei, and F. Brear, SAE transact. 107, 683 (1998). https://www.jstor.org/stable/44736561

7. J. Samet, S. Buist, R. Bascom, J. Garcia, M. Lipsett, J. Mauderly, D. Mannino, C. Rand, and I. Romieu, M. Utell, G. Wagner, D. V. Bates, M. L. Billingsley, M. Gelobter, B. F. Hobbs, S. Kleenberger, N. K. Leidy, S. London, W. F. McDonneli, D. Schwela, and J. C. Wiley, Am. J. Respir. Crit. Care Med. 161, 665 (2000). https://doi.org/10.1164/ajrccm.161.2.ats4-00

8. M. M. Hossain, A. K. Majumder, M. Islam, and A. A. Nayeem, Am. J. Pure Appl. Biosci. 1, 12 (2019). https://doi.org/10.34104/ajpab.019.0191219

9. S. K. Guttikunda and M. Khaliquzzaman, Air Quality, Atmos. Health 7, 103 (2014). https://doi.org/10.1007/s11869-013-0213-z

10. IQAir, World Air Qaulity Report, Region and City $\mathrm{PM}_{2.5}$ Ranking (2019). https://www.iqair.com/world-most-polluted-cities

11. The Economist Intelligence Unit (EIU), The Global Liveability Index, A Free Overview, 1-14 (2018). https://www.eiu.com/public/topical_report.aspx?campaignid=Liveability2018

12. F. J. Kelly and J. C. Fussell, Environ. Geochem. Health 37, 631 (2015). https://doi.org/10.1007/s10653-015-9720-1

13. M. M. Rana, N. Sulaiman, B. Sivertsen, M. F. Khan, and S. Nasreen, Environ. Sci. Pollut. Res. 3, 17393 (2016). https://doi.org/10.1007/s11356-016-6950-4.

14. J. Duan, Y. Chen, W. Fang, and Z. Su, Procedia Eng. 102, 1150 (2015). https://doi.org/10.1016/j.proeng.2015.01.239

15. X. Gang, L. Jiao, B. Zhang, S. Zhao, M. Yuan, Y. Gu, J. Liu, and X. Tang, Aerosol Air Quality Res. 17, 741 (2017). https://doi.org/10.4209/aaqr.2016.09.0406

16. B. A. Begum, S. K. Biswas, A. Markwitz, and P. K. Hopke, Aerosol Air Quality Res. 10, 345 (2010). https://doi.org/10.4209/aaqr.2009.12.0082

17. B. A. Begum, S. K. Biswas, and M. Nasiruddin, J. Bang. Acad. Sci. 34, 33 (2010). https://doi.org/10.3329/jbas.v34i1.5490

18. IPCC, 2001: Climate Change 2001: The Scientific Basis. Contribution of Working Group I to the Third Assessment Report of the Intergovernmental Panel on Climate Change, Cambridge University Press, Cambridge, United Kingdom and New York, NY, USA. https://www.ipcc.ch/site/assets/uploads/2018/03/WGI_TAR_full_report.pdf

19. B. A. Begum, S. K. Biswas, P. K. Hopke, and D. D. Cohen, Aerosol Air Quality Res. 6, 334 (2006). http://www.aaqr.org/files/article/1368/1_AAQR-06-12-OA-0001_334-359.pdf

20. A. Salam, T. Hossain, M. N. A. Siddique, and A. M. S. Alam, Air Quality, Atmos. Health 1, 101 (2008). https://doi.org/10.1007/s11869-008 0017-8.

21. B. A. Begum, P. K. Hopke, and A. Markwitz, Atmos. Pollut. Res. 4, 75 (2013). https://doi.org/10.5094/APR.2013.008

22. B. A. Begum, S. K. Biswas, and P. K. Hopke, Sci. Total Environ. 358, 36 (2006). https://doi.org/10.1016/j.scitotenv.2005.05.031

23. B. A. Begum, A. Hossain, N. Nahar, A. Markwitz, and P. K. Hopke, Aerosol Air Quality Res. 12, 1062 (2012). https://doi.org/10.4209/aaqr.2012.05.0138

24. CASE, Clean Air and Sustainable Environment Project (2018). http://case.doe.gov.bd

25. M. A. Hossen, and A. Hoque, J. Civil Const. Environ. Eng. 3, 10 (2018). https://doi.org/10.11648/j.jccee.20180301.13

26. X. Yang, L. Jiang, W. Zhao, Q. Xiong, W. Zhao, and X. Yan, Int. J. Environ. Res. Public Health 15, 1 (2018). https://doi.org/10.3390/ijerph15071382

27. B. A. Begum, S. K. Biswas, and P. K. Hopke, Atmos. Environ. 45, 7705 (2011). https://doi.org/10.1016/j.atmosenv.2010.10.022

28. M. M. Rana, and M. H. Khan, Asian J. Atmos. Environ. 14, 47 (2020). https://doi.org/10.5572/ajae.2020.14.1.047

29. CASE, Clean Air and Sustainable Environment Project (2014). http://case.doe.gov.bd/ 
30. B. A. Begum, and P. K. Hopke, Aerosol Air Quality Res. 18, 1910 (2018). https://doi.org/10.4209/aaqr.2017.11.0465.

31. A. Ommi, F. Emami, N. Zikova, P. K. Hopke, and B. A. Begum, Aerosol Air Qual. Res. 17, 475 (2017). https://doi.org/10.4209/aaqr.2016.07.0304

32. D. L. Yue, M. Hu, Z. J. Wu, S. Guo, M. T. Wen, A. Nowak, B. Wehner, A. Wiedensohler, N. Takegawa, Y. Kondo, X. S. Wang, Y. P. Li, L. M. Zeng, and Y. H. Zhang, Atmos. Chem. Phys. 10, 9431 (2010). https://doi.org/10.5194/acp-10-9431-2010

33. B. A. Begum, E. Kim, S. K. Biswas, and P. K. Hopke, Atmos. Environ. 38, 3025 (2004). https://doi.org/10.1016/j.atmosenv.2004.02.042

34. D. Zhao, H. Chen, E. Yu, and T. Luo, Adv. Meteorol. 2019, ID 5295726 (2019). https://doi.org/10.1155/2019/5295726

35. I. Kayes, S. A. Shahriar, K. Hasan, M. Akhter, M. M. Kabir, and M. A. Salam, Global J. Environ. Sci. Manag. 5, 265 (2019). https://doi.org/10.1155/2019/5295726

36. A. K. Majumder, A. A. Nayeem, N. A. Patoary, and W. S. Carter, J. Air Pollut. Health 5, 33 (2020). https://doi.org/10.18502/japh.v5i1.2857 